\title{
Effects of Argument-based Science Inquiry (ABSI) Approach Used in the Unit of "Reproduction Growth Development in Living Beings" on the Success Levels of Students ${ }^{i}$
}

\author{
Eda Pınar Tüccaroğlu ${ }^{1}$, Yeter Şimşekli ${ }^{2, *}$ \\ ${ }^{1}$ Science Teacher, Hasan Güney Secondary School, Bursa, Turkey \\ ${ }^{2}$ Faculty of Education, Uludağ University, Bursa, Turkey
}

Copyright $\mathrm{C} 2018$ by authors, all rights reserved. Authors agree that this article remains permanently open access under the terms of the Creative Commons Attribution License 4.0 International License

\begin{abstract}
In this study, it was aimed to examine the effects of the argument-based science inquiry (ABSI) approach used in the unit of "Reproduction, Growth, Development in Living Beings" on the academic achievement levels of students. The sample of the study was composed of a total of 88 students at Dilek Özer Secondary School in the Nilufer district of Bursa. The study was carried out with three 6th grade classes. Two of these classes were determined as the experimental group and one class was chosen as the control group. In the study, while the experimental group was taught the unit of "Reproduction, Growth, Development in Living Beings" in accordance with the ABSI method, the control group was not intervened in any way. The study was completed in five weeks. Prior and subsequent to the study, a pre-test and a post-test were administered with the aim of collecting data. The mixed method was employed in the study. In order to collect qualitative data, the lessons taught in the experimental and the control groups were tape-recorded. Then, the sets of data obtained from the sound recordings were converted to tables by making content analysis. The sets of quantitative data obtained in the study were compared by using the 'independent samples t-test' and the 'dependent samples t-test' in the spss program. As a result of the analysis of the sound recordings, while the rate of teacher dialogues was low and that of student dialogues was high in the experimental group, the opposite was observed in the control group. Moreover, while there was not a significant difference between the experimental and the control group in terms of the mean scores obtained from the achievement test, a significant difference was found between the experimental group's pre-test and post-test score means.
\end{abstract}

Keywords Argument-based Science Inquiry (ABSI), Science Education, Academic Success, Dialogue Analysis,
Reproduction Growth Development In Living Beings.

\section{Introduction}

Argumentation is making an inference about an event based on scientific data. And the argument-based science inquiry approach, too, includes such processes as uncovering, evaluating and discussing students' existing foreknowledge, guiding students to structure concepts and achieving the realization of conceptual change in learning environments where research and inquiry are dominant [1]. In our country and other countries, learning by inquiring, reasoning and questioning is gaining importance. The development of these skills in students can be possible through experiencing the processes of explanation, reasoning, claiming, presenting evidence and mounting an argument [2]. Thanks to this method, students' discussion skills develop while learning.

Argumentation plays a big role in science. Krummheuer [3] defined argumentation as the purposeful explanation of the reasoning of a solution during or after the development of it. Siegel [4] put forward the idea that it is always aimed to propose a reasonable solution to a problem in an argument. Toulmin [2] determined the basic factors composing an argument as data, claim, and reason. According to Toulmin [2], these are the fundamental requirements for mounting an argument.

According to Zohar and Nemet [5], more places should be given to scientific argumentation in science teaching at schools, for scientific argumentation helps to teach students how to defend their opinions by using data and proofs. If students do science lessons with right and proper discussions, that is to say, by mounting arguments, 
meaningful learning can be achieved. For a person putting forward his/her opinions with claims and proofs means he or she is using his or her mental activity at upper level. Hence, that person can achieve in-depth learning.

In the new science education program [6], it is emphasized that just experimentation and discovery are not sufficient for permanent and meaningful learning, but in addition to the structuring of knowledge, the processes of explanation, reasoning, claiming, presenting proof and mounting an argument should be given place.

Studies on the use of ABSI in primary education revealed that argumentation and discussion methods increased students' academic success, reasoning and discussion skills and also positive attitudes towards science education $[7,8,9]$.

In a study carried out with the ninth grade students, in the groups where the ABSI approach was used, a significant difference was found in terms of course success, participation in lessons and benefiting from activities [10]. When the studies carried out with students taking undergraduate education were examined, it was determined that the ABSI approach developed the academic success levels and discussion skills of the students [11].

In the renewed science education program in our country [6], it is aimed to have students learn the science concepts by actively participating in lessons and experiencing and internalizing. To achieve this, teaching based on argumentation and discussion was emphasized as a teaching method and technique in the program.

ABSI is a teaching approach aiming to develop students' skills of searching-questioning, discussion, reasoning and explanation. In a study on high school students' discussion skills, it was determined that the students' skills such as expressing opinions, taking a subject from a different point of view, reasoning were insufficient [13]. Similarly, in domestic $[13,14]$ and international $[15,16]$ studies, it was determined that the students' skills of analyzing given information, examining a subject from different perspectives and critical thinking were insufficient.

ABSI, showing parallelism with the objectives of the new science education program [6], is a method which is likely to contribute to the development of students' discussion skills, help their internalizing information and develop their searching-questioning, reasoning skills.

The purpose of this study is to examine the effect of the "Argument-Based Science Inquiry (ABSI)" approach on the academic achievement levels of the 6th grade students in the "Reproduction, Growth, Development in Living Beings" unit of the subject of science and technology.

For this purpose, answers were sought to the following questions.

1. What are the rates of dialogues used in the experimental and the control groups?
2. Does the use of the ABSI approach in the unit of "Reproduction, Growth, Development in Living Beings" affects the students' achievement levels?

\section{Method}

\subsection{Research Model}

In the study, the experimental design was used. The experimental design is the design where participants are randomly assigned to an experimental group and another group to which experimental procedure is not applied. Here, changes in pre-test and post-test results of individuals in both groups after the procedure is applied to the experimental group are compared [17]. The in-class dialogues and the sets of data obtained as a result of the pre-test and the post-test composed the qualitative and quantitative data sets.

This study was carried out during the 2013-2014 educational year at Dilek Özer Secondary School located in the Nilufer district of Bursa. Of the three 6th grade classes, two were chosen as the experimental group and one as the control group. While the unit of "reproduction, growth, development in living beings" was taught via the argumentation approach by taking into account the acquisitions specified by the Ministry of National Education (MNE) in the experimental group, the subjects of the same unit were taught in the control group without making any intervention in the teaching method. All the students were administered a pre-test prior to the study and a post-test following the study. In order to determine the number of discussions and dialogues made with both the experimental and the control groups, the lessons were tape-recorded. The sets of tape-recorded data were transcribed in the computer environment.

\subsection{Research Sample}

The sample of the study was composed of 88 students from three different 6th grade classes of Dilek Özer Secondary School located in the Nilufer district of Bursa. In the study, the convenience sampling method was used. The convenient sample is the name given to a group best representing a population by bearing its characteristics when it is not possible to research the whole of it [18]. The experimental group included 58 students (two classes) and the control group was composed of 30 students (one class). Since some students did not attend classes, the sample of the study included a total of 84 students (55 experimental, 29 control) attending all the classes during the study process. Also, in the analysis of the data, the sets of data obtained from a total of 84 students attending all the classes in which the unit was taught were used. 


\subsection{Data Collection Tools}

In this study, two different data collection tools were used.

1) Sound recordings

2) Achievement test

"Sound recordings" were composed of the recordings made during the practice. The "achievement test" was compiled from questions asked in previous exams [19]. The achievement test applied as the pre-test and the post-test was composed of 20 multiple-choice questions. The reliability coefficient of the achievement test was found as (KR-20) 0.54. According to this result, the test was acceptable as reliable [20].

\subsection{Data Analysis}

From the beginning until the end of the study, sound recordings were made in the lessons and then the dialogues were transcribed one by one in the computer environment. Hence, the numbers of the teacher and the student dialogues in the experimental and the control groups were determined.

In the analysis of the data obtained from the achievement test, first of all, the score which the students could get from each test item was determined as 2,5. The students got 2,5 points for a correct answer and 0 point for an incorrect answer. The maximum point to get from this test composed of 20 questions was 50 . In order to test if there was a difference between the experimental group and the control group in terms of academic success, t-test was applied to the scores of the pre-test and the post-test administered to the groups.

\section{Findings}

In this study, the results of the qualitative and the quantitative analyses of the sets of data obtained as a result of the teaching done with the experimental group in accordance with the ABSI method and the ones obtained from the control group were presented. Firstly, the findings related to the numbers of dialogues obtained from the sound recordings of the experimental and the control group students and teachers and secondly the findings related to the students' achievement levels were taken in hand.

The graphs belonging to the frequencies of the teacher and the student dialogues obtained from the sound recordings of the experimental and the control groups while the unit of "reproduction, growth, development in living beings" was being taught were shown in Figure 1 and Figure 2.

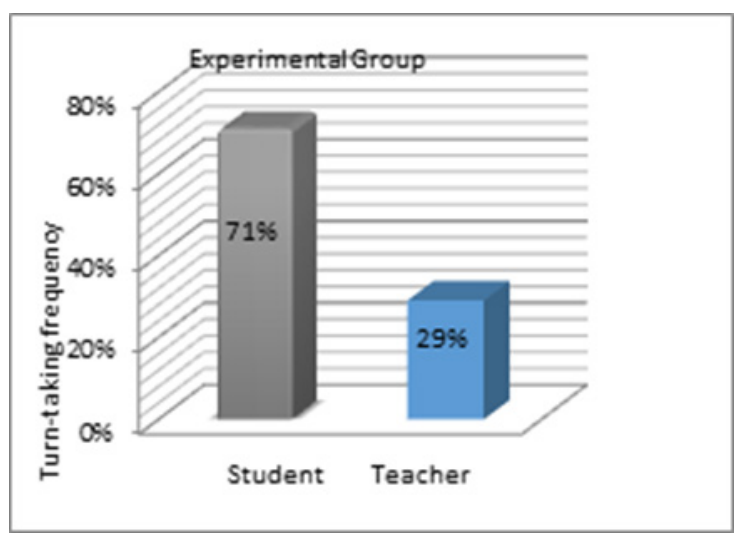

Figure 1. Dialogue percentages of the students and the teachers in the experimental group

When Figure 1 was examined, it was determined that the experimental group students' turn-taking frequency was $71 \%$. However, the teachers' turn-taking frequency was $29 \%$. As it is seen in the figure, the experimental group students' lesson participation rates are rather high. The teacher tried to undertake the duty of a guide during the lessons.

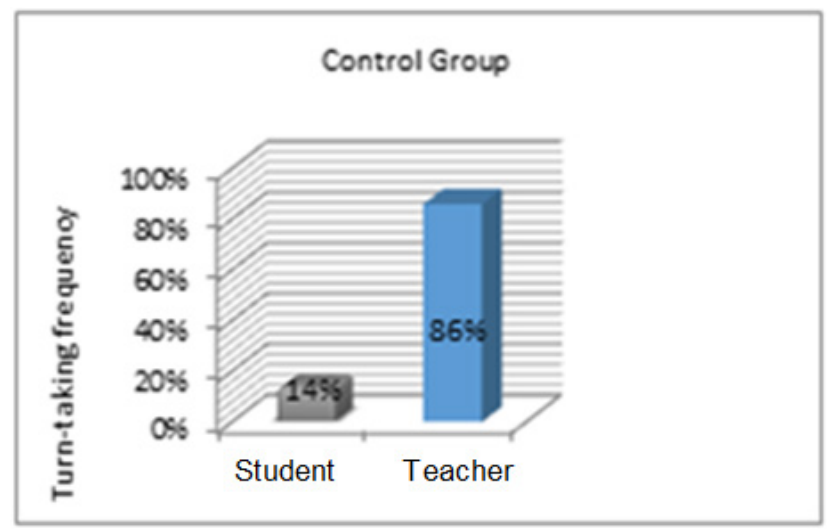

Figure 2. Dialogue frequencies of the students and the teachers in the control group

When Figure 2 was examined, it was determined that the turn-taking frequency of the control group students was $14 \%$. On the contrary, the turn-taking frequency of the teachers was $86 \%$. As it is seen in the figure, the teacher is more dominant in the lesson in the control group. It is observed that the students' active participation in the lesson was low. In classrooms where such dialogues are observed, students are usually passive and one-way communication is more frequently observed.

In order to understand if there was a significant difference between the means of the achievement scores obtained by the students in the experimental and the control groups from the pre-test, the independent samples t-test was applied and the findings were given in Table 1. 
Table 1. Independent samples t-test of the experimental and the control groups' achievement pre-test scores

\begin{tabular}{ccccccc}
\hline Group & $\mathrm{N}$ & $\mathrm{X}$ & $\mathrm{S}$ & $\mathrm{Sd}$ & $\mathrm{t}$ & $\mathrm{P}$ \\
\hline Experimental & 55 & 40.76 & 7.5 & 82 & -1.46 & $0.894^{*}$ \\
\hline Control & 29 & 43.75 & 11.6 & & & \\
\hline
\end{tabular}

$* \mathrm{p}>0.05$

When the pre-test achievement scores of the experimental and the control group students were examined before teaching the unit of "reproduction, growth and development in living beings", it was found that while the mean of the experimental group was (X) 40.76, that of the control group was (X) $43.75 \mathrm{t}(82)=0.894, \mathrm{p}>0.05$. These values indicate that there was not a significant difference between the academic achievement levels of the experimental and the control group students at the beginning.

The independent samples t-test values of the post-test scores obtained by the students in the experimental and the control groups were given in Table 2 .

Table 2. Independent samples t-test of the experimental and the control groups' achievement post-test scores

\begin{tabular}{ccccccc}
\hline Group & $\mathrm{N}$ & $\mathrm{X}$ & $\mathrm{S}$ & $\mathrm{Sd}$ & $\mathrm{t}$ & $\mathrm{P}$ \\
\hline Experimental & 55 & 45.07 & 9.42 & 82 & -1.46 & $0.149^{*}$ \\
\hline Control & 29 & 44.55 & 10.25 & & & \\
\hline
\end{tabular}

$* \mathrm{p}>0.05$

According to the result of the analysis, when the post-test achievement scores were examined, it was found that the mean of the scores obtained by the students in the experimental group was (X) 45.07, that of the scores obtained by the control group was (X) $44.55 \mathrm{t}(82)=0.149$, $p>0.05$. These results indicated that there was not a significant difference between the academic achievement levels of the experimental and the control group students after the practice. When the means of the achievement pre-test and post-test scores of the students in the experimental and the control groups were examined, it was observed that the mean of the scores obtained by the students in the experimental group increased as a result of the practice. For this reason, in order to examine the relationship between the experimental group and the control group students' achivement pre-test and post-test scores, the dependent samples t-test was applied.

The dependent samples t-test values belonging to the pre-test and post-test achievement scores obtained by the students in the control group were given in Table 3.

Table 3. Dependent Samples T-Test of the Control Group Students' Achievement Pretest and Post-Test Scores

\begin{tabular}{ccccccc}
\hline Group & $\mathrm{N}$ & $\mathrm{X}$ & $\mathrm{S}$ & $\mathrm{Sd}$ & $\mathrm{t}$ & $\mathrm{P}$ \\
\hline Experimental & 29 & 43.75 & 10.25 & 28 & 4.16 & $0.680^{*}$ \\
\hline Control & 29 & 44.55 & 10.25 & & & \\
\hline
\end{tabular}

$* \mathrm{p}>0.05$

According to the analysis, while the mean of the scores which the students in the experimental group took from the mutiple-choice questions of the pre-test was determined as $\left(X_{\text {control }}=43.75\right)$, that of the scores which they took from the multiple-choice questions of the post-test was determined as $(X$ control $=44.55)(\mathrm{t}(28)=0.680 \mathrm{p}>0.05)$. A significant difference was not found between the means of the scores obtained by the students in the control group from the multiple-choice questions of the pre-test and the post-test.

The dependent samples t-test values belonging to the pre-test and the post-test scores obtained by the students in the experiental group were given in Table 4.

Table 4. Dependent Samples T-Test of the Experimental Group Students' Achievement Pre-test and Post-Test Scores

\begin{tabular}{ccccccc}
\hline Group & $\mathrm{N}$ & $\mathrm{X}$ & $\mathrm{S}$ & $\mathrm{Sd}$ & $\mathrm{t}$ & $\mathrm{P}$ \\
\hline Experimental & 55 & 40.76 & 10.88 & 2.936 & $0.005^{*}$ & \\
\hline Control & 55 & 45.07 & 10.88 & & & \\
\hline
\end{tabular}

$* \mathrm{p}<0.05$

According to the analysis, while the mean of the scores which the students in the experimental group took from the multiple-choice questions of the pre-test was found as (X experimental $=40.76)$, the one of the scores which they took from the multiple-choice questions of the post-test was found as $\left(\mathrm{X}_{\text {experimental }}=45.07\right)(\mathrm{t}(54)=0.005 \mathrm{p}<0.05)$. A significant difference was found between the means belonging to the multiple-choice questions of the experimental group's pre-test and post-test.

\section{Discussion}

The purpose of the study was to examine the effect of the ABSI approach on the students' academic success levels in science lessons. For this purpose, while the experimental group was administered a teaching enriched via ABSI, the control group was administered a non-intervened teaching. When Figure 1 and Figure 2 are examined, it is observed that while the turn-taking frequency of the experimental group students is $71 \%$, that of the control group students is $14 \%$. This indicates that the teacher in the experimental group tried to undertake the duty of a guide during the course. In this way, the teaching in the experimental group tried to be made effective by increasing the number of dialogues in the lessons of this group. That the argument-based science inquiry increases conceptual understanding and reasoning skills was revealed by other studies as well [7,8]. Kaya [12] investigated the effect of dialogues occurring in science lessons on learning and reached the result that the dialogues between the teachers and the students contributed to the students' internalizing information.

When the pre-test and the post-test achivement scores of the experimental and the control group students were compared, it was determined that there was not a significant difference between the groups according to the 
independent samples t-test. When the achivement pre-test and post-test score means of the experimental and the control groups were examined, it was observed that the mean of the experimental group increased as a result of the practice. For this reason, with the aim of examining the treationship between the achievement pre-test and post-test scores of the experimental group and the control group students, the dependent samples $t$ test was applied and a significant difference was found between the experimental group's pre-test and post-test scores. According to these results, it can be stated that the argument-based science inquiry (ABSI) is one of the practices aiming to increase students' success. These results show parallelism with those obtained in similar studies $[7,21]$

In conclusion, it can be inferred from the results of this study that the ABSI approach is one of the practices aiming not only to motivate students to participate in in-class dialogues but also increase their achievement levels. For this reason, it is important to give place to the ABSI approach in science education programs. However, in order to apply the method successfully, programs should be developed with the aim of increasing the knowledge and skill levels of teachers and preservice teachers in relation to the approach.

\section{Abbreviations}

ABSI : Argument-Based Science Inquiry

\section{REFERENCES}

[1] Nussbaum, J. \& Novick, S. Alternative Frameworks, Conceptual conflict and accommodation: toward a principled teaching strategy, Instructional Science, No.11, 183-20, 1982.

[2] Toulmin, S. The uses of argument. Cambridge University Press, Cambridge, 1958.

[3] Krummheuer, G. Theethnography of argumentation. In P. Cobb\& H. Bauersfeld (Eds.), Emergence of mathematical meaning. Hillsdale, NJ: Lawrence Erlbaum, 1995.

[4] Siegel, H. Why should educator scare about argumentation?, Informal Logic, 17, 159-176, 1995.

[5] Zohar., A. \& Nemet, F. Fostering students' knowledge and argumentation skills through dilemmas in human genetics. Journal of Research in Science Teaching, Vol.39, No.1, 35-62, 2002.

[6] Milli Eğitim Bakanlığı,Temel Eğitim Genel Müdürlüğü,
Fen bilimleri dersi öğretim programı (ilkokul ve ortaokul 3,4,5,6,7,8. sinıflar), Ankara, 2017.

[7] Özkara, D. Teaching pressure subject to eighth class students with activities based on scientific argumentation, Yüksek Lisans Tezi, Adıyaman Üniversitesi, 2011.

[8] Ceylan, K.E. İlköğretim 5. sınıf öğrencilerine dünya ve evren öğrenme alanının bilimsel tartışma( ATBÖ) odaklı yöntem ile öğretimi, Yüksek Lisans Tezi, Gazi Üniversitesi, 2012.

[9] Yeşildağ Hasançebi F.\& Günel, M. Effects of argumentation based inquiry approach on disadvantaged students science achivement, Elementary Education Online, Vol.12, No.4, 1056-1073, 2013.

[10] Günel, M., Kıngır, S., \& Geban, Ö. АTBÖ yaklaşımının lise öğrencilerinin kimya derslerinde argümantasyon tabanlı bilim öğrenme yaklaşımının uygulanmasına ilişkin görüşleri, Ahmet Keleşoğlu Eğitim Fakültesi Dergisi, No.32, 17- 27, 11.

[11] Demirbağ, M., \& Günel M. Integrating argument based science inquiry with modal representations: impact on science achievement, argumentation, and writing skills, Kuram ve Uygulamada Eğitim Bilimleri, Educational Sciences: Theory \& Practice, Vol.14,No.1 , 373-392, 2014.

[12] Kaya, O. N. Tartışma teorisine dayalı öğretim yaklaşımının ögrencilerin maddenin tanecikli yapısı konusundaki başarılarına ve bilimin doğası hakkındaki kavramalarına etkisi, Yayımlanmamış Doktora Tezi, Gazi Üniversitesi, 2005.

[13] Uluçınar Sağır, Ş. Fen bilgisi dersinde bilimsel tartışma odaklı öğretimin etkililiğinin incelenmesi, Yayımlanmamış Doktora Tezi, Gazi Üniversitesi, 2008.

[14] Yıldırım, C. Bilim tarihi. Remzi Kitabevi, İstanbul, 2009.

[15] Jiménez - Aleixandre, M.P., Rodríguez, A.B., \& Duschl, R. "Doing the lesson" or "doing science": argument in high school genetics, Science Education, 84, 757- 792, 2000.

[16] Erduran, S., Simon, S., \& Osborne, J. TAPpinginto argumentation: developments in the application of toulmin's argument pattern for studying science discourse. Wiley Periodicals, Inc. (USA), 2004.

[17] Robson, C. Bilimsel araştırma yöntemleri: gerçek dünya araştırması. Anı Yayıncılık, Ankara, 2015.

[18] Çepni, S. Araştırma ve proje çalışmalarına giriş. Trabzon, 2010.

[19] Fenokulu, http://www.fenokulu.net/yeni/Genel-Dosyalar/Son-15-yild a-6-sinif-5-unite-cikmis-sorular_2059.html' den alınmıştır.

[20] Şencan, H. Sosyal ve davranışsal ölçümlerde geçerlilik ve güvenirlik, Seçkin Matbaası, Ankara, 2005.

[21] Okumuş, S. Maddenin halleri ve isı ünitesinin atbö yöntemi ile öğretiminin öğrenci başarısına ve anlama düzeyine etkisi, Yüksek Lisans Tezi, Karadeniz Teknik Üniversitesi, 2012.

i This study was prepared by summarizing a part of the master thesis entitled "Analysis of the effects of argument-based science inquiry approach utilized within the unit of "reproduction, growth and development in living beings" on the reasoning skills and success levels of students" done under the supervision of Asst. Prof. Dr. Yeter Şimşekli. 